\title{
Ecological Apocalypse in the Poetry of Patrick and Emily Brontë
}

\author{
Simon Marsden
}

check for

updates

Citation: Marsden, Simon. 2021. Ecological Apocalypse in the Poetry of Patrick and Emily Brontë. Religions 12: 546. https://doi.org/10.3390/ rel12070546

Academic Editor: Alison Milbank

Received: 13 June 2021

Accepted: 15 July 2021

Published: 19 July 2021

Publisher's Note: MDPI stays neutral with regard to jurisdictional claims in published maps and institutional affiliations.

Copyright: (c) 2021 by the author Licensee MDPI, Basel, Switzerland. This article is an open access article distributed under the terms and conditions of the Creative Commons Attribution (CC BY) license (https:// creativecommons.org/licenses/by/ $4.0 /)$.
Department of English, University of Liverpool, Liverpool L69 7ZG, UK; s.j.marsden@liverpool.ac.uk

\begin{abstract}
This essay considers relationships between nature, ecology and apocalypse in the poetry of Patrick Brontë (1777-1861) and Emily Brontë (1818-1848). It argues that though Patrick's poetry emphasises the spiritual benefits of human connection with the natural world, his apocalypticism leads him to see no eschatological future for the natural world. Emily's poetry is more attentive to destruction and violence in the natural world, but it also offers an eschatological vision of a future in which all of creation participates. Reading Emily's poetry in theological conversation with that of her father, this essay argues that Emily reinterprets Patrick's evangelical apocalypticism in the light of her understanding of God as the eternal source of all finite being. Drawing on a theological view of creation as God's eternal relationship with the earth, Emily suggests that meaningful eschatological hope can be located only in a future in which the whole of creation participates with the human.
\end{abstract}

Keywords: apocalypse; eco-theology; poetry; Emily Brontë; Patrick Brontë

In August 1842, while a student at the Pensionnat Heger in Brussels, Emily Brontë wrote a short essay in French that she titled 'Le Papillon' ('The Butterfly'). The essay begins with a scene of apparent natural tranquillity in which the narrator is unable to believe: 'It was summer; the sun was still shining high in the west and the air resounded with the songs of birds. All appeared happy, but for me, it was only an appearance' (Brontë 1996, p. 176). Adopting a naturalist's gaze that strikingly anticipates Charles Darwin's invitation, at the conclusion of his On the Origin of Species (1859), to contemplate an entangled bank and to see the history of competition and destruction that has shaped its apparent stability (Darwin [1859] 1996, pp. 395-96), Emily's narrator perceives the violence beneath the superficial beauty of the summer day:

All creation is equally mad. Behold those flies playing above the brook; the swallows and fish diminish their number every minute. These will become, in their turn, the prey of some tyrant of the air or water; and man for his amusement or his needs will kill their murderers. Nature is an inexplicable problem; it exists on a principle of destruction. (Brontë 1996, p. 176)

Moments later, Emily's narrator embodies this 'principle of destruction' when she crushes a caterpillar that she finds hidden within the petals of a flower. Destroying the caterpillar in retribution for its own destruction of the plant that shields it, the narrator interprets her action as analogous to the judgment that God should have enacted upon the earth at the time of humanity's first sin. As she lifts her foot from the caterpillar, however, the narrator glimpses a butterfly and hears an 'inner voice' that delivers a rebuke to her nihilistic conclusion:

Let not the creature judge his Creator; here is a symbol of the world to come. As the ugly caterpillar is the origin of the splendid butterfly, so this globe is the embryo of a new heaven and a new earth whose poorest beauty will infinitely exceed your mortal imagination. And when you see the magnificent result of that which seems so base to you now, how you will scorn your blind presumption, in accusing Omniscience for not having made nature perish in her infancy. (ibid, p. 178)

The butterfly as a symbol of resurrection appears to have been a topic given to Emily by her tutor; Charlotte Brontë, also a student at the Pensionnat Heger, wrote an essay on a 
similar theme on the same day (Charlotte titled hers 'The Caterpillar'). Emily's approach to the task, however, is illustrative of her own theological imagination and, particularly, of her interpretation of the apocalyptically-inflected Evangelical Christianity in which she had been raised. The butterfly was and is a conventional Christian metaphor for resurrection, but Emily's deployment of this metaphor invests it with another shade of theological nuance. The butterfly appears not simply as consolation in the face of death, but as a rebuke to the individual who sees only a cycle of violence in nature and seeks to enact upon it the judgment that God withholds. The butterfly represents a transformed future state that the narrator has denied to the caterpillar but which, the 'inner voice' insists, God will not deny to the created world.

Evangelical echoes in Emily's work have often been regarded sceptically by literary critics: Margaret Homans, for example, has read apocalyptic passages such as those in 'The Butterfly' as instances of a constraining orthodoxy that silences the individual voice of the poet (Homans 1980; cf. Tayler 1990; Davies 1994). Indeed, as Micael M. Clarke has shown, Brontë scholarship from the 1960s onwards came to be dominated by secular critical perspectives that not only regarded Emily as a rebel against Christianity, but also identified this rebellion as a source of much of the creative power of her work (Clarke 2009). Critics working in this secular tradition of literary scholarship have tended to underestimate the theological latitude within Christianity and to see criticism of religion in texts in which nineteenth-century readers might have recognised more nuanced exploration of theological questions. For example, Janet Gezari has claimed that in Emily's writing only 'characters situated at a considerable psychological distance from their creator ... imagine a happy afterlife for disembodied spirits in a place resembling a Christian paradise or heaven' (Gezari 2007, p. 50). Gezari's identification of Christian eschatology with this 'happy afterlife for disembodied spirits' is a reductive reading of a theological tradition steeped in imagery of resurrection and renewal; not least because, as Judith Wolfe has pointed out, nineteenth-century theology saw a significant shift toward a view of the eschaton as in some way continuous with earthly life in the present (Wolfe 2019; cf. Wheeler 1990; Wright 2003). As I will argue in this essay, Emily's poetry does suggest that she saw little appeal in the prospect of a disembodied afterlife. Instead, she found in the Christian apocalyptic tradition a language in which to imagine the renewal of the created world and a vision of an eschatological future in which nature would participate with humanity.

My aim in this essay is to demonstrate that Emily Brontë's apocalyptic poetics represents a subtle but significant reinterpretation of the apocalyptic eschatology familiar to her from her Evangelical background. I want to consider Emily's work in theological and imaginative conversation with the Evangelical writer with whose career and faith she was most intimately familiar: her father, the Rev. Patrick Brontë. An Evangelical clergyman who published two volumes of poetry and several prose works on religious and political themes, Patrick's literary career has been almost entirely overshadowed by those of his daughters; indeed, his own published poetry is rarely mentioned in critical studies of his daughters' work. The last two decades, however, have seen the beginnings of a renewal of interest in Patrick's poetry, prompted in part by the emergence of new perspectives on his life and ministry. Juliet Barker's landmark biography The Brontës (1994) offered a significant revision to Elizabeth Gaskell's portrayal of Patrick as an eccentric and distant father in her Life of Charlotte Brontë (1857), while Dudley Green's Patrick Brontë: Father of Genius (Green 2008) provided a detailed account of Patrick's ministry as perpetual curate of Haworth from 1820 until his death in 1861, including his significant achievements in improving education and sanitation in the town. In the years between the publication of these two biographies, Marianne Thormählen's The Brontës and Religion (Thormählen 1999) argued that the Brontë sisters' Evangelical upbringing encouraged, not strict doctrinal adherence, but the intellectual freedom with which they approached religious matters in their writing. Christine A. Colón takes up this point in a discussion of Patrick's influence on his daughters, concluding that 'independence of thought was actually encouraged by some Evangelicals like Patrick Brontë, for while he may not have agreed with all of his 
daughters' conclusions, he certainly would have recognized the value of his daughters grappling with the truths of Christianity for themselves' (Colón 2014, p. 263).

Despite this growing acknowledgment of Patrick's theological influence on his daughters, literary critics have so far paid little attention to the ways in which his own attempts at literary expression of his theology formed part of this influence. As the daughters of a minor Evangelical poet whose modest library formed a significant part of their early reading, Emily and her sisters inherited from their father not only a theology, but a theological poetics. Patrick's two published poetry collections-Cottage Poems (1811) and The Rural Minstrel (1813)-are often didactic in tone, motivated by his desire to evangelise, but they are also texts in which his Evangelical theology intersects with his reading of Romantic and pastoral poetry. Patrick's poems articulate his understanding of Christian faith as embodied in human action, contemplation and community, and as situated within specific locations-landscapes, cottages, villages, churches, hillsides, ruins-that inspire emotional and imaginative responses in the believer. These embodied responses of faith to material reality, however, are ultimately orientated away from the earth and toward heaven. Patrick's apocalypticism allows material existences to be read as a collection of signs that point to the eternal, but it also renders those existences transient; in Patrick's poetry, a properly theological imagination always sees present reality in the light of its imminent end. In this respect, I want to suggest that Emily Brontë refigures her father's theological poetics by insisting on human communion with the natural world as integral to the eschaton. Where Patrick invites his readers to contemplate a world that will soon pass away, Emily offers an image of present reality as the 'embryo of a new heaven and a new earth' (Brontë 1996, p. 178), intimating that the eschaton might be understood not as a break with material reality, but as the fulness and completion of its present, imperfect embodiment.

This essay, then, examines the relationship between nature and eschatology in Patrick's poetry and the ways in which Emily reframes this relationship by imagining the eschaton not as a break with present material existence, but rather as a future that is immanent within and emerges from that existence. Where Patrick sees in the natural world a series of signs that point the believer away from transient nature and to the permanence of heaven, Emily's poetry is attentive to the changes and cyclical rhythms of nature that hint at a future for the earth and provide images of organic continuity between present and future realities. I begin by discussing the apocalypticism of Patrick's poems and its theological orientation away from nature and toward the eternal, before moving to a reading of Emily's poetry as a reimagining of Patrick's understanding of apocalypse. I conclude with some reflections on the value of the Brontës' theological poetics for contemporary environmental and ecological thought.

\section{The End of Nature}

For Patrick Brontë, as for many Evangelicals of his era, the world of nature was a system of legible signs that, if read with the right kind of spiritual discernment, disclosed both the work of God in creation and the imminent destruction of nature when God would bring this world's history to an end. Though he undoubtedly believed in an eternal future for the faithful 'Where time, and chance, shall be no more,/And joy eternal reigns' (Brontë 1898, p. 45), the language in which he imagines this future is consistent in separating it from the natural world of the present. Patrick writes about the natural world with a Romantic sensibility, seeing in it the grace and creative activity of God, but he does not imagine a future for nature in or beyond the eschaton. In a sermon of 1824 (one of only two of Patrick's sermons to be published, a consequence of his practice of preaching without a written text), Patrick praises those of his parishioners who 'in deep contemplative mood [... ] saw by faith through nature to nature's God' and were able to discern in a recent bog burst on the Haworth moors a sign of God's impending judgment (Brontë 1898, p. 217). These discerning readers of nature, able to recognise and heed the divine warning, are the faithful who, at the last day, will 'fearlessly and triumphantly survey the wreck of universal nature, when the sun shall be turned into darkness, and the moon into blood-when the 
stars shall fall from their orbits, and the heavens and the earth shall dissolve in flames, and pass away' (p. 219). Patrick situates the faithful outside of nature, at a vantage point from which they can behold the destruction of the created world.

This eschatological vision of nature's end would seem to support Timothy Morton's contention that 'Christian apocalypticism shares with deep ecology a fundamental lack of concern for the way things are going. Since the end of the world is nigh, or since we will all become extinct in the long run, there isn't much point in caring' (Morton 2010, p. 27). Though, as Emma Mason points out, Morton's account 'reduces Christianity to a one-dimensional simplification of fundamentalist Evangelicalism, and so leaves no room for the history of radical Christian ecology' (Mason 2018, p. 22), the Christian imagining of nature's divinely-appointed end remains a significant aspect of Christianity's ecological legacy. In Patrick's poetry, we see how human spiritual flourishing might continue to be associated with a close connection to the natural world despite the presence of an underlying apocalyptic eschatology. Among Patrick's most significant poetic influences, after all, was William Wordsworth, in whose poetry Jonathan Bate finds the ecological conviction that '[h] umanity only survives in nature. Human survival and the survival of nature are therefore co-ordinate with one another' (Bate [1991] 2013, p. 34). Yet Patrick's poetry also reveals as a theological consequence of his apocalypticism the need to regard this human connection with nature as transient. For Patrick, humanity survives ultimately not in nature but in God; indeed, his poetry locates the human's eternal survival outside of and beyond the natural cosmos that will be brought to its end at the last day. A life lived in connection with nature might inspire faith and encourage simple contentment, while the landscape itself is filled with signs that point the faithful reader to the divine. These signs, however, direct the believer's gaze away from the world and towards the eternal. The material forms of nature might point toward the divine, but the divine is not allowed to be present sacramentally within those forms and nature is not imagined as participating in the eschatological future.

Patrick's poem 'The Happy Cottagers', published in his first collection Cottage Poems, is indicative both of Patrick's sympathies for a simple life lived in close connection with the natural world and of his reluctance to ascribe sacramental significance to the ordinary routines and environments of such lives. The poem describes a visit to a rural cottage in which the speaker, likely an imagined version of Patrick himself on an idealised pastoral visit, shares a meal with the cottager and his daughter. Like many of Patrick's poems, 'The Happy Cottagers' articulates a belief in the spiritual advantages of the rural cottager's simple life over the vanities of the fashionable, worldly rich. After the meal, the cottager breaks into a prayer of thanksgiving, a reflection of the practice of spontaneous, nonritualistic prayer that Lori Branch has shown to be associated with authentic expression of faith in Evangelical traditions (Branch 2006). The cottager incorporates the meal into the language of his prayer, but resists the eucharistic implications of the 'clean, and dazzling bright' vessels placed on the 'snowy white' table-cloth (Brontë 1898, p. 80). The meal is read analogically rather than sacramentally:

He prayed, that for his sake,

Whose guiltless blood, was shed

For guilty ruined man;

We might that day, be fed

With that pure bread,

Which cheers the soul;

And living stream

Where pleasures roll. (p. 81)

The physical elements of the meal prompt the cottager to think of their spiritual equivalents: Christ the bread of life (John 6: 25-40); Christ the source of living water (John 4: 10-14). The meal itself, however, lacks the liturgical context that Catherine Pickstock describes as one in which 'every meal should only occur as a ritual feast, thus drawing everyday life towards a ritual mode just as much as vice-versa' (Pickstock 1998, p. 174). The 
meal inspires the cottager to think of the bread and water of life, but it is not understood as mediating those divine gifts or as constituting the Christian community that receives them. 'The Christian involved in the celebration of the Eucharist', Rowan Williams argues, 'is not affirming a set of propositions [ ... ] but inhabiting, in speech and action, a drama which purports to "re-locate" him or her in the space occupied by Jesus Christ in his eternal relationship with the Father, a relocation which is enabled by his sacrificial death and his rising from the grave and ascension into heaven' (Williams 2012, p. 92). Patrick's poem holds the meal apart from this liturgical context. The meal is an act of fellowship between believers and a source of symbols for the divine gifts of eternal life, but these gifts are not mediated by the material elements of the meal itself. The eternal is not encountered sacramentally in the meal and a liturgical community is not constituted in the sharing of it.

As an Anglican minister, of course, Patrick presided at the Eucharist and administered the sacraments of the Church. He defended the Church of England's practice of infant baptism against a Baptist critic in a treatise published in 1836 (Brontë 1898, pp. 233-51). As a poet, however, he did not locate divine presence in the rhythms or material objects of ordinary life. A simple life lived in close connection with the natural world could bring spiritual contentment and inspire worship of God, while also protecting the rural cottager from the temptations and vices of the worldly and powerful. In Patrick's theological poetics, nature is a source of signs that warn of divine judgment and reveal the availability of grace. Nature is a fertile source of metaphors with which to imagine eternity, but the eternal is not present in nature and nature will not endure with the believer into eternity. The divine call upon human lives can be mediated by nature, as it is in 'The Sabbath Bell' when the 'solemn sound' of the eponymous bell blends with a chorus of natural sounds:

Perched on the milk-white thorn, the linnet sweetly sings;

The labouring bee, shakes music, from his mellow wings:

Loud tolls the Sabbath Bell (p. 72)

The poem sets the sound of the sabbath bell in harmony with the sounds of nature, allowing them to merge into a unified call to worship that reminds the hearer of the transience of their mortal life and the need to fix their hopes in heaven. The sabbath bell links the present world to the future, as its sound is heard again in the presence of a heavenly choir of saints:

There, for the solemn Bell, will sweetly sound,

The notes of heavenly music, ever new;

There, for the summer sun, will beam around,

The rays of grace,

From Jesu's face (pp. 75-76)

If the sabbath bell and the sunrise hint at a superficial continuity between temporal present and eschatological future, the imagery also reveals a more profound rupture. The sabbath bell and the sunrise are incorporated into the vision of the future only as absences, recalled in the images of heavenly music and divine light that will stand in for them in eternity. The poem's pastoral scene provides a series of images and analogies with which to imagine eternal life, but those images remain the only form in which nature endures into eternity. Nature gestures allegorically to the eternal life of the believer, but Patrick does not imagine the natural world as participating in that eternal life.

In 'Kirkstall Abbey, A Fragment of a Romantic Tale', Patrick articulates both his understanding of the natural world as closely connected to human flourishing and his belief in the ultimate transience of nature. The poem's subtitle locates its depiction of the Abbey within the tradition of the Romantic ruin, while also perhaps hinting at a more personal connection to the location: Patrick had walked to Kirkstall Abbey with Maria Branwell during their courtship in 1812 (Barker [1994] 2010, p. 61). The poem imagines the Abbey in moonlight, as a mysterious-perhaps mythical-singer invests the scene with sacred and solemn tranquillity. Under the gentle influence of the moonlit Abbey, Patrick suggests, 
The fond, unloaded breast,

Unruffled, will regain its rest,

And every anxious throbbing quell,

And each oppressive sigh;

E'en wakeful jealousy will die,

The slighted lover's hell. (Brontë 1898, p. 79)

Moonlight and song imbue the abbey and its surroundings with sublime tranquillity that calms the human spirit and turns thoughts to the divine. Like the sabbath bell in the preceding poem, the ruined abbey merges with its natural surroundings-'How heavenly fair, the arches ivy-crowned,/Look forth on all around' (p. 78) — to yield spiritual truth for the night-time wanderer. Those who come to the abbey will find turbulent emotions calmed by its soothing influence; resentments and jealousies will fade 'Amid this lovely scene,/So solemnly serene' (p. 79). For the person of faith, the abbey will inspire a more profound encounter with God:

Here, faith may stretch her wings and fly,

To regions far beyond the sky,

And dwell with God above;

Whilst each celestial flame will play,

Around the heart, with melting sway,

And all the soul, be love. (p. 79)

This response of feeling and faith to a scene of natural tranquillity carries echoes of the conception of 'spiritually inspired poetry' that Helen Boyles identifies in Wordsworth's Lyrical Ballads as 'based on a more elemental conception of religion as the spirit of good which motivated the higher aspirations of human life and influenced a harmonious relationship with the natural world' (Boyles 2017, p. 99). Patrick allows the landscape of Kirkstall Abbey to exercise this benevolent influence on the night-time wanderer, but he also signals throughout the poem that the spiritual benefits derived from nature are grounded in the creative agency of the Christian God. Any visitor to the abbey, Patrick suggests, might receive the spiritual consolations of nature, but only those who read the scene through the eyes of Christian faith will perceive its fullest meaning and learn to look beyond the landscape itself and to God; these faithful alone will live on 'when all things decay;/ And heaven, and earth, and time, shall pass away' (Brontë 1898, p. 78). The theological meaning of nature is realised fully only by a perspective of faith that looks beyond nature and toward eternity. Nature inspires the best of human moral impulses and aspirations, while also revealing the creative agency and grace of God. Yet nature remains that which will pass away at the end of time. To grasp the full extent of nature's divine revelation is to recognise nature itself as transient and to 'anchor all [one's] hopes, beyond the skies' (p. 78).

\section{Re-Writing Apocalypse}

As the mysterious song that runs through 'Kirkstall Abbey' nears its conclusion, Patrick offers a final image of the spiritual contentment that it inspires in the believer:

If lively faith exert her matchless power,

And love celestial crown the blissful hour,

Here, worlds themselves, may pass away,

And sun, and moon, and stars decay,

Here, all the glories of the skies burst on the sight,

And shed their pure effulgence bright,

On the enraptured eyes;

Whilst all around, sweet Eden's roses blow,

And heaven's own blessings o'er the bosom flow. (pp. 79-80)

Trusting in the eternal and surrounded by the flowers that become the remnants of Eden, the believer experiences a serene calm that remains impervious even to decay and 
destruction on the cosmic scale. In 'Extemporary Verses, Written at a Reverend Friend's House, During his Absence', the poem that follows 'Kirkstall Abbey' in The Rural Minstrel Patrick returns to the image of a faithful Christian retaining their spiritual tranquillity in the midst of cosmic annihilation. In this poem, the apocalyptic implications of the imagery become explicit:

Though outward storms should blow with heaviest gust,

And lightnings flash, and deepening thunder roll;

Though day should hide his face in eddying dust,

Old ocean heave, earth shake, from pole to pole;

Though reeling stars, their jarring spheres confound,

And heaven pass, in wild affright, away;

Though wild chaotic roar, throughout resound,

Armed with the terrors of the judgment-day;

Unmoved, alone, the faithful soul will stand,

With brow serene,

Survey the scene,

Upheld, and comforted, by God's Almighty hand. (p. 82)

In each of these poems, Patrick imagines believers surveying a cosmic catastrophe from which they remain protected by divine grace. The collapse of the cosmos, the destruction of nature and the delivery of God's final judgment hold no fears for the faithful Christian, who remains assured of eternal life by the saving grace of God. Reflecting the didactic and evangelistic aims of his poetry, Patrick emphasises the individual believer's eternal security in the face not only of the trials of life, but of the final apocalyptic overthrow of nature.

A similar image of universal destruction in what is perhaps Emily Brontë's best-known poem, 'No coward soul is mine' (1846), hints at a nuanced intertextual relationship with her father's apocalypticism. Where Patrick's poetry emphasises the security of the faithful believer in the face of apocalyptic judgment, Emily draws universal nature and the human into a theological vision of a God who is both source and sustainer of all being:

Though Earth and moon were gone

And suns and universes ceased to be

And thou wert left alone

Every Existence would exist in thee

There is not room for Death

Nor atom that his might could render void

Since thou art Being and Breath

And what thou art may never be destroyed (Brontë 1992, p. 182)

Echoing her father's image of 'sun, and moon, and stars' decaying, Emily rewrites its theological significance to affirm not simply the eternal security of the believer, but the endurance in eternity of all matter regardless of its transience within temporal existence. The poem's theological vision is of a God whose relationship with nature is characterised by eternal creativity; whose 'spirit animates eternal years' and 'Changes, sustains, dissolves, creates and rears' (p. 167). Mortality and destruction remain facts of temporal existence, but nothing is truly lost in death because all things are held together by God who is the source of all being and in whom all existence is eternally contained. Lisa Wang rightly sees in this poem an expression of 'a confident belief in God's all-pervasive, life-giving Spirit' (Wang 2000, p. 166). From its opening claim of personal union with this Spirit-the 'God within my breast' of the second stanza (Brontë 1992, p. 182)—the poem expands into a theological vision of God's relationship to the whole of creation. Emily's view of a God in whose eternity are contained all the changes and mutability of finite existence recalls Augustine's discussion of creation and time in the Confessions. Heaven and earth, Augustine argues, 'cry aloud that they are made, for they suffer change and variation' (Augustine 1992, p. 224). Time and change are signs of contingent existence, both distinct 
from and grounded in the 'simultaneity of eternity' (Augustine 1992, p. 226). As Janet Martin Soskice observes, 'God, for Augustine, is Being Itself and the source of all being' (Soskice 2015, p. 155). Emily in 'No coward soul is mine' can assert boldly that nothing in nature is truly lost to death because the poem's theological vision is one in which all of temporal being is unified and held together in eternity.

Emily's most overtly apocalyptic poetry makes clear that she interpreted the apocalypse as a renewal of creation; not a future in which humanity would be separated from nature, but one in which nature would participate with the human. In the conversation poem 'Anticipation', one of Emily's speakers responds to her pessimistic interlocutor with the affirmation that

'It is hope's spell that glorifies,

Like youth, to my mature eyes,

All Nature's million mysteries,

The fearful and the fair -(Brontë 1992, p. 13)

Looking toward 'what is to be' (p. 13), the speaker retains the joy in natural beauty that is lost to her world-weary companion. Though the poem gives little detail of the anticipated future, it associates eschatological hope with the continued perception of beauty and joy in nature. 'A Day Dream' offers a clearer picture of the apocalypse as the renewal of nature. The poem begins with its speaker unable to participate in the joy of seasonal change, which she imagines as a nuptial celebration: 'It was the marriage-time of May/With her young lover, June' (Brontë 1992, p. 17). Like the narrator of 'The Butterfly', the speaker regards the appearance of natural joy as deceptive. Spring and summer bring new vitality to the natural world, but this will revert to death and decay with the coming of winter. The speaker's awareness of the transience of all life prevents her from entering into the joy of the summer day. These pessimistic reflections are interrupted by an apocalyptic vision in which 'glittering spirits sung,/Or seemed to sing, to $\mathrm{me}^{\prime}$ (p. 18). From the perspective of eternity, the spirits insist, mortality is a blessing, because it leads into a renewal of life:

'To thee the world is like a tomb,

A desert's naked shore;

To us, in unimagined bloom,

It brightens more and more! (p. 18)

Where the speaker sees only the futility of inevitable death, the poem's apocalyptic vision offers an eternal perspective from which nature is seen to flourish endlessly. Barbara Munson Goff has found in Emily's writing 'an intuitive, religious version of the theory of natural selection, derived, as Darwin's was, from close observation of nature and a profound respect for its driving forces, the simultaneity of creation and destruction, the laws of conservation of matter and energy' (Goff 1984, p. 485). Goff's assessment is helpfully alert to Emily's close observation of the natural world and to her familiarity with some popular works of natural science, but it also crucially overlooks the importance of eschatology in Emily's theological poetics. Emily recognised that destruction and decay were inherent to the cycles of nature, but she was also able to see in these cycles the roots of a fuller flourishing of nature that was recognisable from the perspective of eternity. Nature's cycles bring death and decay, but they also enable the seasonal renewal that adds to the plenitude and infinite variety of creation. From the perspective of eternity, unbounded by situatedness in time, this variety appears in all its fullness. The speaker's despondent perception of a world in which all things tend toward decay is interrupted by an eternal viewpoint that sees death itself as interconnected with life's flourishing. From this perspective, the world becomes a site of 'unimagined bloom' that 'brightens more and more'; not a denial of death, but an affirmation of an eternal flourishing within which mortal transience is subsumed.

Emily's poetry often commits only tentatively to this apocalyptic hope: the spirits of 'A Day Dream' only 'seemed' to sing to the speaker, while the poem ends on the 
less-than-confident claim that 'Fancy, still, will sometimes deem/ Her fond creation true' (Brontë 1992, p. 19). Some critics have read this apparent hesitancy as undermining the vision's credibility or as signalling Emily's dissatisfaction with an orthodox Christian resolution. I suggest, however, that Emily's hesitancy can be better understood as a version of what Gavin Hopps has described as 'faithful scepticism' in Wordsworth's poetry: a poetic 'attempt to be simultaneously faithful to radically different orders of reality' (Hopps 2006, p. 61). Emily's apocalyptic poetry invokes an eternal perspective on nature while also acknowledging that such a perspective represents a way of knowing and seeing that can only come from beyond the temporal world of nature to which the poet remains bound. In this sense, the apocalypse offers a fundamentally different way of experiencing nature, rather than a revelation of truths that can be confirmed or refuted by empirical observation of nature. It is a hope grounded in imaginative possibility rather than empirical certainty. As the poem's imagery makes clear, however, this eschatological hope is for all living things: the apocalyptic vision appears as a response to the universal transience of nature, not to the speaker's perception of her own mortality. The spirits' revelation offers the possibility that the speaker's perception of nature might change and that, seeing the natural world with the consciousness of eternity, she might now be able to enter into the nuptial celebration from which she excluded herself at the beginning of the poem. The possibility of eternal flourishing glimpsed in the vision enables the renewal of the speaker's experience of the natural world in the present.

Emily's most overtly apocalyptic poetry, then, demonstrates the theological nuance with which she rewrote her father's apocalypticism into a vision of an eschatological future for the whole of creation. J. Hillis Miller has described a 'double vision of the world' in Emily's poetry: 'The world is at once the ugly sight it appears to mortal eyes, and at the same time those same elements glorified and transformed into their opposites' (Miller 2000, p. 202). Death, violence and transience remain facts of the natural world even as they are seen in the context of their future transformation. For Miller, there is no continuity between Emily's two visions: 'Between this life and the world to come there is no likeness', Miller argues, 'even though this life with all its horror and discord is a necessary prelude to the harmony of heaven' (Miller 2000, p. 201). This influential reading misses the extent to which Emily's poetry identifies eschatological hope as a source of transformed experience in the present: those of her speakers who look toward 'what is to be' (Brontë 1992, p. 13) are also those most able to perceive beauty in the world of the present. Perhaps more significantly, Miller also overlooks the radical continuity between present and future in Emily's version of apocalypse. In 'I see around me tombstones grey' (1841), for example, Emily's speaker explicitly repudiates the prospect of a disembodied afterlife in favour of a future shared with the earth, whether in eternal rest or resurrected life:

We would not leave our native home

For any world beyond the Tomb

No-rather on thy kindly breast

Let us be laid in lasting rest

Or waken but to share with thee

A mutual immortality -(Brontë 1992, pp. 132-33)

The poem affirms the profound connection between the human and the earth as the foundation of its eschatological hope. Those disembodied souls in heaven could achieve their paradise only by forgetting their earthly sorrows and losing their connection with the earth itself. Such an afterlife, Emily suggests, represents a loss of the self and its history. Because human identity is formed in and through connection with the earth, only a future shared with the earth can offer real hope to the human. An eschatology in which nature does not participate-the kind of apocalyptic future imagined in Patrick Brontë's poetry-is an eschatology in which human beings cease to be themselves.

Emily's poem 'Loud without the wind was roaring' exemplifies her understanding of human identity as inseparable from the places and natural landscapes in which it is formed. Written in 1838 while Emily was a teacher at Law Hill school, near Halifax, the 
poem explores memory, imagination and the longing for home. Alone on a dreary autumn evening, the speaker recalls lines of a song that lift her spirits and summon memories of familiar scenes. The poem becomes a celebration of nature's vitality that shows Emily's typical attentiveness to its movements and sounds, as well as to the simple pleasure of physical connection with the landscape. The poem emphasises the ways in which the speaker has lived with the landscape, experiencing it through all of the senses: she recalls a time when she and her companions (perhaps Emily and her siblings) 'traversed the meadows of dew' (Brontë 1992, p. 87), drawing attention to the wetness of the moorland and its physical contact with the speaker's body.

In its final stanzas, the poem returns to the autumnal setting of its opening and focuses on the moorland heath that links the speaker to the landscapes of her memory:

What language can utter the feeling

That rose when, in exile afar,

On the brow of a lonely hill kneeling

I saw the brown heath growing there.

It was scattered and stunted, and told me

That soon even that would be gone

It whispered, 'The grim walls enfold me

I have bloomed in my last summer's sun'

But not the loved music whose waking

Makes the soul of the Swiss die away

Has a spell more adored and heart-breaking

Than in its half-blighted bells lay-

The spirit that bent 'neath its power

How it longed, how it burned to be free!

If I could have wept in that hour

Those tears had been heaven to me-

Well, well the sad minutes are moving

Though loaded with trouble and pain-

And sometime the loved and the loving

Shall meet on the mountains again - (pp. 87-88)

Like many of Emily's poems, these stanzas confront the transience of nature. The seasonal decline of the heath becomes a metaphor for the inevitable mortality of all living things; the speaker's grief in response to this decline emphasises the depth of her emotional and psychological connection with the landscape. The poem's final lines, however, offer a counterpoint to the grief of the preceding stanzas, looking to a future reunion of 'the loved and the loving'. This ambiguous phrase is suggestive of cyclical renewal, articulated in curiously non-specific terms: the 'loved and the loving' may refer to the speaker and the heath, or perhaps to the speaker and her childhood companions, but they might also be read as types encapsulating all those who will love and be loved on the mountains in the future. Though the poem is not overtly apocalyptic, these final lines nevertheless hint at a future renewal that emerges from the seasonal rhythms of nature. The transience represented by the dying heath is caught up at the poem's end into the larger rhythms of time that will bring the loved and the loving together on the mountains again.

Emily's poetry, then, subtly but significantly reinterprets the understanding of apocalypse that was integral to her father's theology and theological poetics. For Patrick, humanity's relationship with the natural world is spiritually beneficial but ultimately transient. Natural beauty brings spiritual tranquillity and a simple life lived in close connection with the natural world protects individuals from the corrupting temptations of worldly riches and vices. Nevertheless, nature belongs to the present order of things that will be 
brought to its end by God; the faithful readers of nature will find their gazes directed away from the earth and toward the eternal. In contrast, Emily does not ask her reader to look from nature to the eternal, but to look back at nature with the perspective of eternity. From this perspective, the violence and decay that she acknowledges in the natural world are revealed as belonging to a greater cycle of flourishing. This mode of seeing requires a commitment to an order of reality beyond the rational or empirical, and in Emily's writing its legitimacy is often threatened by the sceptical voice of reason. Yet this understanding of eternity remains for Emily the only possible basis for eschatological hope in a world in which human personhood is shaped by and through its connections with place and landscape. Only in an eschatological future shared with the earth can human beings remain themselves; only an eternity in which God holds together and unifies all temporal existence can offer meaningful hope to humans facing their own mortality and the transience of all that surrounds us.

\section{Conclusions: A Future for the End}

In an essay published in 2015, Susan Pyke situates Emily Brontë within a tradition of what she calls 'eco-divine literature' that 'might lead to more sustainable lifeways by encouraging a closer attentiveness to country' (Pyke 2015, p. 174). In Pyke's reading of Wuthering Heights, Cathy Earnshaw is an example of a character whose identity is shaped in connection with a familiar and beloved landscape. Cathy 'listens to the flow of the moor and gives it the flow of her life' (Pyke 2015, p. 176); separated from the moor as the wife of Edgar Linton at Thrushcross Grange, she becomes unrecognisable to herself. As I have attempted to demonstrate in this essay, Emily's poetry similarly offers depictions of human being as realised most fully in connection with the more-than-human world. Her interpretation of the apocalyptic tradition develops this insight not simply by positing an eschatological future for the natural world, but by suggesting that only a future in which the whole of creation participates can offer meaningful hope for humanity.

Reading Emily's poetry in conversation with that of her father draws attention to the limitations, from an ecological perspective, of an apocalyptic theology that understands eschatology as a separation of the human from the created world. Patrick is a useful case study in this regard because his own faith was closely interconnected with his love of the natural world. Patrick's Evangelicalism was influenced significantly by his reading of Romanticism, allowing him to find in the natural world a source of spiritual enrichment and divine revelation. His poetry finds spiritual tranquillity not only in generic visions of nature, but in places that he knew personally: Kirkstall Abbey, where he had walked with friends including his future wife; the lakes and hills of his native Ireland. He reminds his readers often that a simple life lived in close contact with the earth could bring a form of contentment that would elude those who pursued more worldly lives. The moral lesson is a conventional one, but Patrick certainly knew that the rural simplicity that he depicts in his poems was already under threat. The Yorkshire parishes in which Patrick ministered were industrialising rapidly and many of his parishioners worked not on the land, but as part of an increasingly globalised trade in textiles. There are few hints of industrialisation and urbanisation in Patrick's writing; in this sense, his poems are nostalgic reflections on a way of life that was already unavailable to many of his parishioners. If, as Norman Wirzba argues, 'at the root of our environmental crisis we find the inability or unwillingness to situate human life within a broadly conceived ecological context' (Wirzba 2003, p. 3), Patrick's poems remind us that nostalgia for the rural contexts of a pre-industrial economy was already a feature of British literature by the early nineteenth century.

Emily's poetry shares with that of her father a sense of longing for a life lived in close connection with the natural world. Such connection is difficult and often transient in her writing, both because of the apparent futility that she sees in nature's own transience and because of humanity's capacity to inflict damage upon the natural world. In one of her last poems, 'Why ask to know the date-the clime?' (1846), Emily depicts a civil war as an act of violence against nature: the harvest is left ungathered, crops are trampled 
underfoot and 'kneaded on the threshing-floor/With mire of tears and human gore' (Brontë 1992, p. 183). The narrative context of the poem is pre-industrial, but its images of the seasonal rhythms of nature disrupted by human activity has a particular resonance with more recent concerns about the impacts of industrialisation on the natural world. Though she understands violence to be integral to the seasonal death and renewal of nature itself, she also sees in damage to nature a material sign of human evil. The apocalypticism of her poetry is rooted in attentiveness to the living things of the natural world-the grass, heather, leaves, bluebells and butterflies-and in the hope of their renewal; human beings, she suggests, are furthest from the divine image when we fail in love for the creation and add to its suffering.

If Emily's writing is more attentive than Patrick's to the cycles of destruction and decay in nature, it is also more willing to imagine encounters with divine life within the created world. The life, vitality and movement of nature is closely associated with her understanding of the creative God who spirit 'Pervades and broods above/Changes, sustains, dissolves, creates and rears' (Brontë 1992, p. 182). As Mark I. Wallace points out in a discussion of sacred places, 'the Bible is awash with rich imagery of the Spirit drawn directly from the natural world. The four traditional elements of natural, embodied life-earth, air, water, and fire-are constitutive of the Spirit's biblical reality as an enfleshed being who ministers to the whole creation God has made for the refreshment and joy of all beings' (Wallace 2007, p. 294). Emily's writing makes extensive use of this imagery, closing the gap that her father saw between the world of material existence and the eternal. Where Patrick sees in the created world a source of signs and metaphors that could direct the faithful observer's gaze toward heaven, Emily imagines the divine as present within the elements and movements of the creation itself. Though her poetry depicts the realities of death and destruction as challenges to the human ability to perceive the divine in nature, she also hints at the possibility of an eternal perspective from which temporal cycles of change and decay are subsumed within an eternal flourishing of all living things. Where Patrick reads the apocalypse as a decisive separation of the human from the created world that provides the context of our mortal lives, Emily finds in the apocalyptic tradition a revelation of God's eternal care for creation and a glimpse of all things being renewed. Like the butterfly that appears in Emily's essay as a symbol of what the caterpillar might have become without the destructive intervention of the narrator, the new heaven and earth is for Emily an image of the creation revealed in all its flourishing, renewed by a God whose infinite care for finite beings holds all existence together in eternity.

Funding: This research received no external funding.

Institutional Review Board Statement: Not applicable.

Informed Consent Statement: Not applicable.

Data Availability Statement: Not applicable.

Conflicts of Interest: The author declares no conflict of interest.

\section{References}

Augustine. 1992. Confessions. Translated by Henry Chadwick. Oxford: Oxford University Press.

Barker, Juliet. 2010. The Brontës, 2nd ed. London: Abacus. First published 1994.

Bate, Jonathan. 2013. Romantic Ecology: Wordsworth and the Environmental Tradition, 2nd ed. London: Routledge. First published 1991. Boyles, Helen. 2017. Romanticism and Methodism: The Problem of Religious Enthusiasm. London and New York: Routledge.

Branch, Lori. 2006. Rituals of Spontaneity: Sentiment and Secularism from Free Prayer to Wordsworth. Waco: Baylor University Press.

Brontë, Emily. 1992. The Complete Poems. Edited by Janet Gezari. London: Penguin.

Brontë, Emily. 1996. The Butterfly. In Charlotte Brontë and Emily Brontë: The Belgian Essays. Translated and Edited by Sue Lonoff. New Haven and London: Yale University Press, pp. 176-85.

Brontë, Patrick. 1898. Brontëana: The Rev. Patrick Brontë, A. B., His Collected Works and Life. Edited by J. Horsfall Turner. Bingley: T. Harrison \& Sons.

Clarke, Micael M. 2009. Emily Brontë's 'No Coward Soul' and the Need for a Religious Literary Criticism. Victorians Institute Journal 37: 195-223. 
Colón, Christine A. 2014. Wrestling with their Father's Faith: Charlotte, Emily and Anne Respond to Patrick Brontë's Christianity. In "Perplext in Faith": Essays on Victorian Beliefs and Doubts. Edited by Alisa Clapp-Itnyre and Julie Melnyk. Cambridge: Cambridge Scholars.

Darwin, Charles. 1996. The Origin of Species. Edited by Gillian Beer. Oxford: Oxford University Press. First published 1859.

Davies, Stevie. 1994. Emily Brontë: Heretic. London: Women's Press.

Gezari, Janet. 2007. Last Things: Emily Brontë's Poems. Oxford: Oxford University Press.

Goff, Barbara Munson. 1984. Between Natural Theology and Natural Selection: Breeding the Human Animal in Wuthering Heights. Victorian Studies 27: 477-508.

Green, Dudley. 2008. Patrick Brontë: Father of Genius. Stroud: Nonsuch.

Homans, Margaret. 1980. Women Writers and Poetic Identity: Dorothy Wordsworth, Emily Brontë, and Emily Dickinson. Princeton: Princeton University Press.

Hopps, Gavin. 2006. 'Je sais bien, mais quand même': Wordsworth's Faithful Scepticism. In Romanticism and Religion from William Cowper to Wallace Stevens. Edited by Gavin Hopps and Jane Stabler. Oxford: Ashgate, pp. 57-74.

Mason, Emma. 2018. Christina Rossetti: Poetry, Ecology, Faith. Oxford: Oxford University Press.

Miller, J. Hillis. 2000. The Disappearance of God: Five Nineteenth-Century Writers, 3rd ed. Urbana and Chicago: University of Illinois Press.

Morton, Timothy. 2010. The Ecological Thought. Cambridge and London: Harvard University Press.

Pickstock, Catherine. 1998. After Writing: On the Liturgical Consummation of Philosophy. Oxford: Blackwell.

Pyke, Susan. 2015. Dream Writing Beyond a Wounded World: Topographies of the Eco-Divine. In Being-in-Creation: Human Responsibility in an Endangered World. Edited by Brian Treanor, Bruce Ellis Benson and Norman Wirzba. New York: Fordham University Press, pp. 173-83.

Soskice, Janet Martin. 2015. Creation and the Glory of Creatures. In Being-in-Creation: Human Responsibility in an Endangered World. Edited by Brian Treanor, Bruce Ellis Benson and Norman Wirzba. New York: Fordham University Press, pp. 143-58.

Tayler, Irene. 1990. Holy Ghosts: The Male Muses of Emily and Charlotte Brontë. New York: Columbia University Press.

Thormählen, Marianne. 1999. The Brontës and Religion. Cambridge: Cambridge University Press.

Wallace, Mark I. 2007. Sacred-Land Theology: Green Spirit, Deconstruction, and the Question of Idolatry in Contemporary Earthen Christianity. In Ecospirit: Religions and Philosophies for the Earth. Edited by Laurel Kearns and Catherine Keller. New York: Fordham University Press, pp. 291-314.

Wang, Lisa. 2000. The Holy Spirit in Emily Brontë's Wuthering Heights and Poetry. Literature and Theology 14: 160-73. [CrossRef] Wheeler, Michael. 1990. Death and the Future Life in Victorian Literature and Theology. Cambridge: Cambridge University Press.

Williams, Rowan. 2012. Faith in the Public Square. London and New York: Bloomsbury.

Wirzba, Norman. 2003. The Paradise of God: Renewing Religion in an Ecological Age. Oxford: Oxford University Press.

Wolfe, Judith. 2019. Eschatology. In The Oxford Handbook of Nineteenth-Century Christian Thought. Edited by Joel D. S. Rasmussen, Judith Wolfe and Johannes Zachhuber. Oxford: Oxford University Press, pp. 676-96.

Wright, Nicholas Thomas. 2003. The Resurrection of the Son of God. London: SPCK. 